\title{
A Case Study of Panthi Dairy Pvt. Ltd. Industrial District, Pokhara
}

\author{
Dr. Dhruba Raj Pokharel ${ }^{1}$
}

\begin{abstract}
A case study of Panthi Dairy Pvt. Ltd. was conducted to bring out the live situations and experiences of an entrepreneur developing the dairy sector. The issues raised in this case are heart breaking as well as heartwarming. The present case study of Panthi Dairy Pvt. Ltd. may contribute to the students and faculties of management in undergraduate and graduate level studying at different universities in Nepal. The experiences shared with the Chair of Panthi Dairy Pvt. Ltd. teach us that every failure is the basement for success. Despite of all other factors, self-study, regulation and control are the major ingredients that contribute to entrepreneurial success.
\end{abstract}

Keywords: Dairy, dairy entrepreneur, dairy company, ice cream, agro-based enterprise

\section{Objectives}

This case study has been carried out to explore the life time reality of the agro based entrepreneur in Nepal. The present case study aims to provide the guidelines for the people interested in the case study. It may also help to the faculties and students to frame the case study and analysis in the class rooms of different universities at different academic levels and programmes.

\section{Methodology}

In order to achieve stated objectives, an in-depth informal interview was conducted with Mr. Panthi in his factory premises. Along with informal discussions twenty questions were asked to Mr. Panthi to frame the case study. Mr. Panthi is a funny person with a positive mind. His personality made it easy to make the interview more friendly and interactive. The ideas shared by him were duly recorded and transcribed. Further, Mr. Panthi added more information which he thought necessary but were missing in the questions. The first draft of this study was sent to him for review and suggestions. The suggestions received from him were incorporated in the final draft. This case study has been presented in the descriptive narrative forms. The interviews for the purpose of this study were carried out on the morning of 16 November, 2015. The initial ideas to conduct this study were developed from reviewing the research papers, books and informal discussions with pioneering personalities in enterprise and entrepreneurship. Due honor is given to the writers by giving their name and their seminal works in the bibliography section of this study.

1 Associate Professor, Faculty of Management, Tribhuvan University, Kirtipur 


\section{Limitations}

This case study of Panthi Dairy Pvt. Ltd. is based on the information provided by the entrepreneurs only. It does not cover the views of the people working in the dairy. It has also not included the views of customers, suppliers and stakeholders of company. Moreover, it carries only the initiating ideas and excluded the financial and marketing aspects of dairy. By the nature, this is the case of Panthi Dairy Pvt. Ltd.; therefore, it cannot be generalized.

\section{Facts Presentation and Discussion}

Mr. Resham Panthi born before 42 years in a farmer's family went to Ganesh Himal to explore it and to have a handful experience that could be used to solve his bread and butter problem in 1986. But due to his physical fitness, he suffered the high altitude sickness and returned to Pokhara. Since he could not succeed the mission, he was eager to search the solutions to his basic problems of food, shelter and cloth. Due to illness caused by high altitude Mr. Panthi started a shop of needle and thread in the centre of lovely Pokhara city at Prithivichowk. This was his first attempt to be in business. It was very small and gave minimum return to him. After some time of its operation it entered into the hardship due to competition, quality and trust of both the suppliers and the customers.

After his bad experience of thread and needle shop he started a business related with sweets in the year of 1989. Panthi Mithai Pasal, a small business also did not favor him. According to him, this shop was also failed due to the lack of skilled manpower, the layout of shop itself, and his expectations. He did not stop his egoistic efforts to make his livelihood himself. Failure after failure, he searched the next way, and established a boarding school at Lekhnath in Pokhara valley. Again he suffered the losses and quit the school. According to Mr. Panthi, his travelling to Biratnagar opened a next door to ideas. In 1989 he experienced the destructive earthquake when he was working as a teacher of mathematics at a reputed school in Biratnagar. He remembers the cinema hall, named Hanuman Takiz and the ice-cream vendor as his learning place and the great Guru in his life. He learnt about the production process, marketing techniques, and many more things related with ice-cream. He also found out the source and price of the machine used for ice-cream production and processing.

With the inspirations gained in Biratnagar, Mr. Panthi returned to Pokhara with zeal to start an ice-cream production unit. His father's positive attitude favored him to contact Nepal Bank Limited to borrow Rs. 100,000 - to purchase an ice-cream processing machine. In the meantime, Indian blockage began during the Rajib Gandhi's regime in India in 1989. After 16 months, Mr. Panthi went to India, but the price of the machine was hiked and the vendor demanded Rs. 50,000 more from him. With support of his father and the manager of Nepal Bank Limited he could buy the machine. He established and registered his business as Panthi Dairy Pvt. Ltd. in the year of 1993 at Chipledunga in Pokhara. Due to limitation of space, he set it up near the Bus Park. Later, in 2009 he successfully bided the land -about fifteen ropanies- inside the Industrial District of Pokhara, and shifted his production unit. 
When, Mr. Panthi is about to explain his past, he takes long breath and tells of the scarcity in his family which was the major inspiration to him to be in today's position. His one after another failures in settingup-of his businesses made him to be a continuous learner, and persistent to his journey of doing something. In addition to what is mentioned above, Mr. Panthi is indebted to his parents, Ram Milan Upadaya, the agro expert of the time, Tika Upreti, and the vendor of ice-cream at Hanuman Takiz in Biratnagar for their positive attitude and estimable support when he was in hardship and distressful time. According to Panthi, the government officials were not supportive and encouraging to the enterprising people like him. In the journey of venturing Mr. Panthi has crossed the different ups and downs. Given the nature of his current business, nobody were ready to rent him the building and premises as dairy machines produce bad sounds and the atmosphere turns bad-smelling. Whatever, his endeavour was to create employment in and outside his factory but he faced the overly politicized employees in his factory. Due to his own lifeline having ups, down and jolts, the people around him were not ready enough to give him trustworthy reputation. Despite of all historical jolts, Mr. Panthi at present is reconstructing and rejuvenating his dairy industry. Despite of all hardship he is able to expand his activities in Kathmandu, the capital city of Nepal.

Mr. Resham Panthi believes in regular hard work, persistent learning and self engagement as the most powerful attributes helpful to his success. He takes every event positively and expresses that every day is a happy day to him irrespective of consequences. He seems to be confident that his brother- a high skilled dairy technician- and daughter- a graduate in micro-biology are ready to take the responsibility of modernizing his business. He aspires that along with his brother and daughter in recent future he will be able to make his company ISO certified.

The major product line of Panthi Dairy Pvt. Ltd. comprises pasteurized milk, yoghurt, cheese, ghee, paneer, mithai, and ice-cream with multiple flavour and taste. Panthi Ice-cream is serving the taste of people with different age group. Its milk, yoghurt, cheese, ghee, paneer and mithai have become the compulsory ingredients of the dishes produced in the personal as well as commercial kitchen around the periphery of Pokhara valley.

Mr. Resham Panthi, the Chair of Panthi Dairy Pvt. Ltd., claims that his industry is more than the contemporary leading dairy companies in private and public sector. He dreams that his company will have the production and maintenance centre for refrigerator vehicle and dairy support equipments. At present, Panthi Dairy Pvt. Ltd. owns four vehicles with refrigerators designed by itself. The company is also planning to produce and supply the dairy product friendly home appliances in near future. Panthi, in long-run, plans to commercially make the Panthi Marga from Muktinath to Pashupatinath making easy availability of its products on the way. He wants to make the chain of dairy products restaurant in Nepal as the fast food chain of giant McDonalds in the world.

The learning experience of Mr. Panthi is inspirational heartwarming to the upcoming entrepreneurs in the 
dairy sector. Panthi sees everything positively and advices to young entrepreneurs enthusiastically. He shares his ideas and advises people to start today (earlier possible) and wait for result with patience and vigour. People usually talk about others, but Panthi believes that try to know yourself through self study about self and be known about you more and less about others. He advocates that there is no good and sound management other than self control and self regulation in own work setting. Knowledge about basic technology and procedures of own business operation is the prime factor of the success of any activities. Therefore, he advices to upcoming entrepreneurs to devote as much as time to learn about the work, its impact on society, and the trend of national economic indicators. Finally Panthi rests with requesting the youths to develop self-confidence and be ready to convert the challenges into opportunities so that youths can transform themselves and their nations.

\section{Conclusions, Implications and Future Study}

The case of Panthi Dairy Pvt. Ltd. concludes that enterprises are not only built-up with success after success but they can be created in the situation of ups and downs and failures too. The present position of Mr. Panthi and his company has been possible by his strong will-power, determination and devotion to do something. Persistent learning and regular works are the major ingredients to support the entrepreneurial activities. Success of Panthi Dairy Pvt. Ltd. shows how entrepreneurs like Panthi can create, invent and implement their ideas to bring the changes in the society by building their self-image.

This study has multi-faceted implications. It can be helpful to promote the entrepreneurial mind among the young people. It helps readers to learn how practical and continuous learning, devotion and regular work can bring the changes in self-image, family and the society. This study draws the attention toward the hidden opportunities in the areas of agro based entrepreneurship, where unorganized economic activities are dominating the economy of the country. This case study has the implications in the areas like entrepreneurship, strategic management, entrepreneurship behavior, and in the broader sense of sociology of entrepreneurship and business.

The future researchers can use this study as a guideline. The areas to study on such type of agro based industrial activities are virgin in Nepal. The future researchers might concentrate on the empirical studies in this aspect to develop the theories relating to work values, culture and believes that the entrepreneurs like Panthi hold in Nepal. This study can also be replicated in other aspects of agro based industries like poultry, husbandry, vegetable and bee farming. It also will help to change the dominating unorganized agro activities in organized entrepreneurial world of sustainable development.

\section{Suggested Readings}

Basma, N; Jones, K; Autio, E; \& Levie, J. (2007). Global Entrepreneurship Monitor 2007 Executive Report. Babson College and London Business School. 
Blars, F.R. \& Ketchen Jr. D.J. (2014). So, you want to be an entrepreneur? Lessons from the entrepreneur? Lessons from the entrepreneurship bootcamp for veterans with disabilities. Business Horizons, 57:5-9

Bruton, G.D., Ahistorm, D., \& Obloj, K. (2008). Entrepreneurship in emerging economies: Where should the research go in the future? Entrepreneurship Theory and Practice, 32(1):1-14

Dana, L.P (2000). Creating entrepreneurs in India. Journal of Small Business Management, 38(1):86-91

Headol, B. (2003). Redefining business success: Distinguishing between closes and failure. Small Business Economics, 21:51-61

Herron, L. \& Sapienza, H. (1992). The entrepreneur and the initiation of new venture launch activities. Entrepreneurship Theory and Practice, 17 (1): 49-60

Ireland, R.D \& Webb, J.W (2007). A cross-disciplinary exploration of entrepreneurship research. Journal of Management, 93: 891-927

Ireland, R.D \& Webb, J.W. (2007). Strategic entrepreneurship: Creating competitive advantage through streams of innovation. Business Horizon, 50:49-59

Littunen, H (2000). Entrepreneurship and the characteristics of the entrepreneurial personality. International Journal of Entrepreneurial Behavior \& Research, 6(6); 395-409

Lumpkin, G.T. \& Dess, G. (1996). Clarifying the entrepreneurial orientation construct and linking it to performance. Academy of Management Review, 21(1); 135-172

Mehrez, A. (2014). A study of barriers to entrepreneurship in emerging economics: The case of Qatar. Proceedings of $29^{\text {th }}$ International Business Research Conference, 24-25, November, Sydney, Australia

Persinger, E.S., C. Emin, \& Vastina, S. W. (2007). The born global entrepreneur in emerging economies. International Business and Economics Research Journal, 6(3):73-82

Share, S; Kolvereid, L. \& Westwood, P. (1991). An exploratory examination of the reasons leading to new firm formation across country and gender. Journal of Business Venturing 6: 431-446

Sharma, G. \& Kulshrestha, K. (2014). Challenges and opportunities of entrepreneurs in emerging economics. International Journal of Public Administration and Management Research, 2(3): 1-8

Sharma, P \& Chrisman, J.J. (1991). Toward a reconciliation of the definitional issues in the field of corporate entrepreneurship. Entrepreneurship Theory and Practice, 23(3):11-27

Stevenson, H.H. \& Jarillo, J.C. (1990). A paradigm for entrepreneurship: Entrepreneurship management. Strategic Management Journal, 11:17-27 